\title{
方向依存性色残効 “マッカロー効果”にともなう色充填現象
}

守田知代 1 , 吉川左紀子 2

(京都大学文学部 1 , 京都大学大学院教育学研究科 2 )

key words: マッカロー効果, 色充填, 視野

\section{目的}

ある色と線分の組み合わせ刺激を数分間見た後，白黒の縞 模様からなるテス卜刺激を見ると, 実際は色の入力がないに もかかわらず薄い色が知覚される。これはマッカロー効果と 呼ばれる方向依存性色残効現象である（McCollough, 1965）。 マッカロー効果による錯覚色は, 現実の色とほとんど同じよ うに知覚されるが，その知覚メカニズムはかなり異なると考 えられている。マッカロー効果には色の充填現象が関わって おり，縞の境界に生じた錯覚のエッジ色が，縞の間に拡散す ることで一様な色知覚が生じると報告されている（Broerse and O'Shea, 1995）。我々は，中心視野に比べて視野角10度 付近の中心外視野において, より強い色錯覚が経験されるこ とを示した（守田・吉川, 2004, 日本視覚学会）。この結果 は, 色の充填が中心外視野でより強く起こることを示唆して いる。本研究では, 色錯覚が生じる視野位置と色充填機能と の関係を明らかにすることを目的とする。上，下，左，右の いずれかの視野位置に, 錯覚または現実の色知覚のどちらか が生じる状況を設定し, それらの色の検出課題における正答 率を比較検討する。

\section{方法}

被験者 正常な視力, 色覚を有する 38 名（男性 17 名, 女 17 名)。平均年齢 : $20.6 \pm 1.5$ 歳。そのうち 18 名の被験者は 実験 1 ，残り 20 名の被験者は実験 2 へ参加した。

刺激および実験条件 マッカロー効果誘導刺激として, 画面 の中央部分 $17^{\circ} \times 17^{\circ}$ の領域に, 黒色と緑色の水平方向の 縞刺激と，黒色とマゼンダ色の垂直方向の縞刺激を 10 秒間 ずつ交互に提示した。またテス卜課題時には, 上下・左右の 偏心度 10 度の位置に, 縞模様からなる半径 $4^{\circ}$ の円刺激が 同時に提示された。テスト課題は，錯覚色知覚条件と現実色 知覚条件からなり, ランダム提示された。錯覚色知覚条件で は, 4 箇所のうちいずれか 1 箇所でマッカロー効果による色 錯覚が生じるよう設定されている。一方, 現実色知覚条件で は，色錯覚は生じないものの，いずれか 1 箇所の刺激に淡い 色があらかじめ塗られており, 色知覚が生じるよう設定され ている。

手続き 両実験ともに, 最初にマッカロー効果誘導刺激が 10 分間提示された。その後に行われたテスト課題の手続きは, それぞれ以下のとおりである。

[実験 1] 被験者は上・下・左・右 4 つの刺激のいずれかに色 が知覚されるかどうかを判断し，できるだけ早くキー押しを 行うよう教示された。ボタン押しが行われるまでテスト刺激 が提示された。被験者のうち半分は右手を, 残り半分は左手 を用いてボタン押しを行った。

被験者内要因 ; テス卜課題時に判断すべき色（錯覚色，現実 色)，ターゲット刺激の視野位置（上，下，左，右） 被験者間要因：ボタン押しを行う手（右手，左手)

[実験 2] テスト刺激が $800 \mathrm{~ms}$ 提示されるので, 被験者は上・ 下・左・右 4 つの刺激のいずれかに色が知覚された場合はそ の位置を, 色が知覚されない場合は「なし」と口頭で回答す るよう教示された。

被験者内要因; テスト課題時に判断すべき色（錯覚色, 現実 色), ターゲット刺激の視野位置（上，下，左，右）
どの視野位置にも色が知覚されない 24 試行を含め, 計 152 試行実施された。すべての課題中, 被験者は常に画面の中央 部を注視するよう教示された。またアイマークレコーダー （ナックイメージテクノロジー製，EMR-NL8）を用いて実 験中の眼球運動の計測を行った。

\section{結果と考察}

実験 1 の正答率に対して, 3 要因分散分析を行ったところ, 色の主効果が有意であり $(\mathrm{F}(1,16)=8.68, p<.01)$ ，マッ カロー効果による錯覚色よりも現実の色に対する正答率が 高いという結果が得られた。また視野位置の主効果も有意で あった $(\mathrm{F}(3,48)=15.32, p<.001)$ 。さらに，視野位置に 関して多重比較を行った結果, ターゲット刺激が上下視野に 提示された場合よりも, 左右視野に提示された場合に正答率 が有意に高いことが示された。被験者間要因である手の主効 果および，その他の要因との交互作用は有意でなかったため, 両群をあわせて表示した（図 A)。

一方, 実験 2 の正答率に対して, 2 要因分散分析を行った 結果, 視野位置の主効果が有意であった $(\mathrm{F}(3,57)=20.32$, $p<.001)$ 。加えて有意な交互作用がみられた $(\mathrm{F}(3,57)=8.70$, $p<.001)$ 。下位検定の結果, 上視野において現実の色よりも マッカロー効果による錯覚色に対する正答率が有意に高か った（図 B)。また誤検出率（FA）は $16.02 \%$ ああった。

これら 2 つ実験結果を比較すると, 錯覚色に対する正答 率は，視野位置によらず，できるだけ早く回答した場合（実 験 1）に比べて，一定時間提示した場合（実験 2）の方が高 かった。実験 1 における平均反応時間は $689 \pm 141 \mathrm{~ms}$ であっ たため, その刺激提示時間は実験 2 よりも短かった。テスト 刺激の提示時間が増加したことによって, 錯覚色に対する検 出力が向上したと考えられ, 刺激が提示された瞬間に色充填 が生じているのではなく, 色の拡散に時間を要すことを示唆 している。

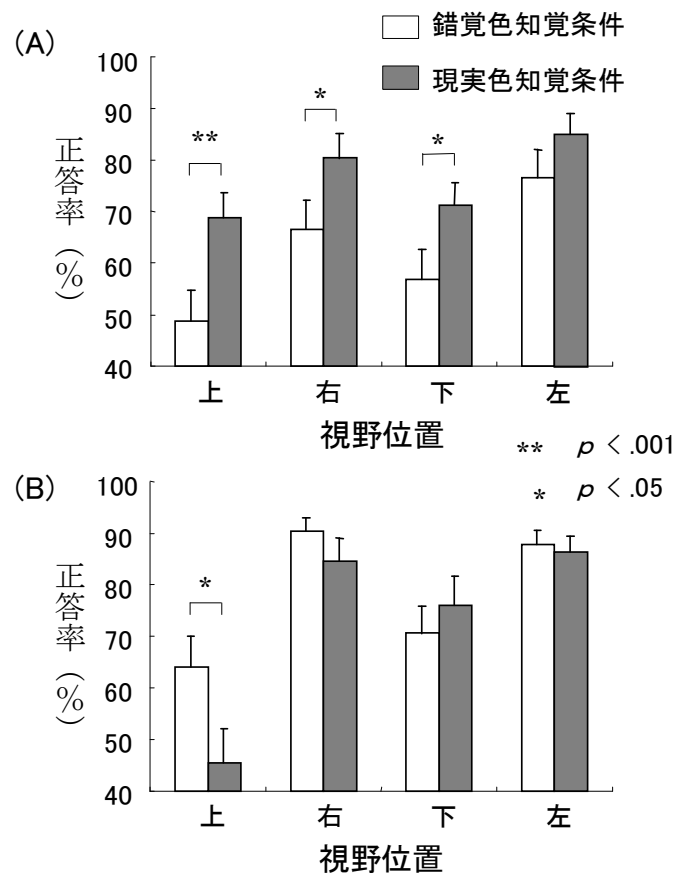

(MORITA Tomoyo • YOSHIKAWA Sakiko) 